\title{
Characterization of sponge cake baking in an instrumented pilot oven
}

\author{
SOMMIER A..$^{a^{*}}$, DUMOULIN E. ${ }^{\mathrm{b}}$, DOUIRI I. ${ }^{\mathrm{b}}$, AND CHIPEAUX C. ${ }^{\mathrm{b}}$ \\ a I2M-TREFLE, Esplanade des arts et Métiers, 33405 Talence, France \\ b Agroparistech, SPAB Dept, UMR GenIAl 1145, F-91300 Massy, France \\ ${ }^{*}$ Corresponding author \\ alain.sommier@ensam.eu \\ TEL: + $33(0) 556845412$ \\ FAX: + $33(0) 556845436$
}

Received: 7 December 2011; Published online: 18 October 2012

\begin{abstract}
The quality of baked products is the complex, multidimensional result of a recipe, and a controlled heating process to produce the desired final properties such as taste, colour, shape, structure and density. The process of baking a sponge cake in a convective oven at different air temperatures (160$180-220^{\circ} \mathrm{C}$ ) leading to the same loss of mass was considered in this study. A special mould was used which allowed unidirectional heat transfer in the batter. Instrumentation was developed specifically for online measurement of weight loss, height variation and transient temperature profile and pressure in the product. This method was based on measuring heat fluxes (commercial sensors) to account for differences in product expansion and colour. In addition, measurement of height with a camera was coupled to the product mass to calculate changes in density over time. Finally, combining this information with more traditional measurements gave a better understanding of heat and mass transfer phenomena occurring during baking.
\end{abstract}

Keywords: baking, instrumentation, oven, sponge cake, volume measurement

\section{Introduction}

Drying, cooking and browning are examples of operations in food processing of cereal products which combine heat and mass transfer. By acting in the core of the product or at the surface, they confer specific technological properties to the final product, such as dimension, water content and mechanical resistance. They are the result of different heat transfer inputs by conduction, convection and radiation, and rate of moisture exchange between product surface and surrounding air. For a better understanding of the mechanisms involved in such processes, data must be acquired using sensors specifically adapted for continuous or batch processes, temperature levels and environment. They provide a range of measurements on line for changing parameters such as product temperature, height, internal pressure and mass. They might be related to process parameters, heat fluxes received by the product, water losses and changes in volume and composition throughout the baking process. Various studies have proposed measuring tools and characterisation methods associated with the properties of the product.

During baking, heat fluxes are received by the product via the surface and through the mould walls or the tray on which it is placed. Pierrel and Newborough (2003) produced oven heat flux maps, and established "baking comfort zones" related to heating mode and product responses 
(colour, volume, structure and moisture content). During baking in an industrial oven, radiative and convective heat fluxes were measured directly using a total heat flux meter travelling through the oven with products. The sensitive element was assumed to have an emissivity similar to the surface of the product (0.90.95). In other cases, the heat flux was calculated from time-temperature recordings (Fahloul, Trystram, Mcfarlane, \& Duquenoy, 1995; McFarlane, 1992; Li \& Walker, 1996; Zareifard, Marcotte, \& Dostie, 2006). The influence of process parameters such as air velocity and temperature have been studied in relation to sponge cake baking (Sato, Matsumura, \& Shibukawa, 1987) where variation in air velocity mainly affected the weight loss (mainly due to water evaporation) via the product surface, especially in the case of forced air convection. Heat transfer by radiation, mainly from walls, affects the product surface temperature and consequently the colour (Standing, 1974) and thickness of crust (Jefferson, Lacey, \& Sadd, 2006), and crust formation influences the volume expansion.

During cake baking there may be changes in height and volume, usually with a reduction in weight, corresponding to variations in apparent density. The consequences are the production of specific structure and porosity of the crumb and crust in relation to the composition of the batter (presence or absence of leavening agent, mixing with air) and to the baking process.

Many studies have reported measuring mass and volume, or density with a pycnometer for the initial liquid batter or in semi-liquid samples taken during the first period of baking (Baik, Marcotte, and Castaigne, 2000a, Baik, Sablani, Marcotte, and Castaigne, 1999, Baker, Davis, and Gordon, 1990). For solid samples or final baked products (crumb and crust), volume has been measured from the dimensions of frozen samples with a regular geometry (Baik et al., 1999), or by a volumetric displacement method (using millet, sesame, rapeseed, glass beads) (Sumnu, Sahin, \& Sevimli, 2005; Sato et al., 1987; Bakshi \& Yoon, 1984; Hwang \& Hayakawa, 1980), or by 3D image analysis (Baik, Marcotte, \& Castaigne, 2000b).

The height variation was recorded continuously for products in a pilot oven, from camera im- ages taken through oven door (and through the mould if any) (Chevallier, Della Valle, Colonna, Broyart, \& Trystram, 2002; Sommier, Chiron, Colonna, Della Valle, \& Rouille, 2005; Lostie, Peczalski, Andrieu, \& Laurent, 2002).

As the final product weight is a quality criterion, weight variation during baking is one of the control parameters. For pilot trials, the product, whether in a mould or not, is usually placed onto a scale (Sommier et al., 2005; Lostie et al. 2002) or suspended under a scale (Hasatani et al., 1992).

Li and Walker (1996) identified optimum process conditions (time, temperature) for baking cakes $(\phi=20 \mathrm{~cm})$ in five different industrial ovens. Volume, crust and crumb colour, texture and baking times were used to evaluate the different processes. Temperature profiles measured inside products (3 thermocouples: bottom, centre and near the surface) were found to be similar for all types of ovens used. Lostie et al. (2002) studied sponge cake baking using a cylindrical mould $(180 \times 150 \mathrm{~mm})$ in an electric pilot oven with static air conditions. Heating only the top surface of the product led to a long cooking time of 4 hours at $200{ }^{\circ} \mathrm{C}$. They recorded continuously the weight of the mould, and the temperatures of the product (3 thermocouples (internal) and pyrometer (surface)). At different baking times, product samples were taken to measure water activity, water content (especially near the surface) and pore size distribution. In the case of French bread, a batch pilot oven was instrumented to monitor the processing conditions and record the physical product properties in real time during baking in different conditions, such as relative batter perimeter (video camera), weight loss and internal temperatures and pressure (Sommier et al., 2005). The role of bubbles and their evolution due to air expansion and increased water vapour pressure have been discussed in many studies, together with the changing rheology of the batter during baking and the crust formation (He \& Hoseney, 1991; Baik \& Marcotte, 2003; Jefferson, Lacey, \& Sadd, 2007).

In summary, various studies at industrial and microscopic levels have been used to understand how the product evolves during baking. Our study dealt with the baking of one model product, a sponge cake, in a mould, in a batch pilot 
electrical oven with hot air circulation, at different fixed temperatures. The objectives were to acquire simultaneously on-line data for the product, as weight loss, expansion, temperature profiles, thickness, internal pressure and to better understand the changing product properties during the baking process.

\section{Materials and Methods}

\subsection{The product}

The sponge cake batter was prepared by gradually mixing different ingredients together at 24 ${ }^{\circ} \mathrm{C}$ (egg yolks and whites with sugar, then flour and water) (Table 1). This recipe, with no leavening agent, was established during an earlier study (Sommier, Ben Yaghlane, \& Broyart, 2002). A stainless steel wire whip with a variable mixing speed was used (KitchenAid Professional, K45SS) with air being introduced during this mixing step. The volume increase was measured and corresponded to $41 \%$ of air in the batter. The initial batter density was calculated from weight and volume measurements, and final cake density was measured by the displacement method using rapeseed $\left(\rho_{\text {seed }}=710 \mathrm{~kg} / \mathrm{m}^{3}\right)$.

\subsection{The baking mould}

The cylindrical mould (Techno Meca, Fr) was built so that heat was transferred to the batter via the bottom (contact and conduction) and surface (air convection and oven wall radiation) (Fig. 1). The insulated wall was made of Teflon $\left(25 \mathrm{~mm} ; \mathrm{l}=0.43 \mathrm{~W} / \mathrm{m} \cdot \mathrm{K}\right.$ at $\left.277^{\circ} \mathrm{C}\right)$ and bottom of aluminium $(12 \mathrm{~mm})$. Video images were taken of the level of the central batter surface inside the mould during baking through a transparent double glass window in the side wall.

The batter was placed in the mould at ambient temperature: $700 \mathrm{~g}, 942 \mathrm{~cm}^{3}, \sim 2.5-3 \mathrm{~cm}$ high. The mould was then quickly placed on the support in the oven, which was preheated to a stable fixed temperature. The sponge cake expanded inside the mould during baking $(\sim$ double height), with a final volume of about $2 / 3$ of the mould volume.

\subsection{The pilot oven}

The batch pilot oven was a prototype (Servathin, Fr), with air controlled for temperature, humidity and velocity, and with a volume of $75 \mathrm{dm}^{3}$ (500 x $500 \times 300 \mathrm{~mm})$ (Fig. 2). Air was heated by 3 elements $(3 \times 5 \mathrm{~kW})$ linked to a PI controller (Eurotherm $900 \mathrm{ECP}, \mathrm{Fr}$ ) for a range of temperatures from 50 to $300 \pm 0.5{ }^{\circ} \mathrm{C}$. To check the temperature uniformity in the oven (4 levels spaced $5 \mathrm{~cm}$ apart), a separate experiment was performed with a grid instrumented with 30 thermocouples (type K) (6 across the width spaced 10 $\mathrm{cm}$ apart, and 5 between front and back spaced $9 \mathrm{~cm}$ apart). Three series of measurements were taken at 3 air temperatures, 150,160 and $170{ }^{\circ} \mathrm{C}$, and with an air flow rate of $3.5 \mathrm{~m} / \mathrm{s}$. Each measurement was replicated 3 times for the 3 levels and positions $(4 \times 30)$ in the oven giving a mean value after stabilisation for 20 minutes. The air temperature variation between inlet and outlet was less than $2{ }^{\circ} \mathrm{C}$. In the zone where the mould was placed, temperature variation was less than $3{ }^{\circ} \mathrm{C}$. In the oven, a small sample of air was aspirated by a pump through a tube to measure the air dew point temperature $(-10$ to $85 \pm$ $0.2{ }^{\circ} \mathrm{C}$ ) (Hygro M4 SIM-12H, General Eastern, USA). The sampling tube was thermostated (80 ${ }^{\circ} \mathrm{C}$ ) to prevent vapour condensation before measurement. A thermocouple (type K) inside the oven measured the air temperature (Fig. 2) and the air relative humidity was calculated from air and dew point temperatures.

\subsection{Measurements during baking}

\subsection{The pilot oven}

The oven was controlled (air heating, fan action) by a computer with data handling software specially developed using Labview (National Instrument, Fr). During baking, all data were recorded (PCI 4351, National Instrument) as follows: weight variations (mould + product), temperatures (product, mould, air oven), air flow rate and dew point temperature. Product pressure measurements and images of expansion were stored for further analysis. Signals were sampled at a period of $18 \mathrm{~s}$ (Fig. 3) 
Characterization of sponge cake during baking process $\mid 147$

Table 1: Sponge cake recipe

\begin{tabular}{lccc} 
Ingredients & $\begin{array}{c}\text { Mass } \\
(\mathrm{g})(\%)\end{array}$ & $\begin{array}{c}\text { Mixing conditions } \\
\text { (mixer index } \mathrm{V} ; \\
\text { measured rate }(\mathrm{tr} / \mathrm{min}))\end{array}$ & $\begin{array}{c}\text { Duration } \\
(\mathrm{s})\end{array}$ \\
\hline Egg white & $195(16.6)$ & $\mathrm{V}=10 ; 286 \mathrm{tr} / \mathrm{min}$ & 10 \\
Egg yolk & $170(14.47)$ & $\mathrm{V}=6 ; 171 \mathrm{tr} / \mathrm{min}$ & 612 \\
\hline Sugar & $365(31.06)$ & $\mathrm{V}=2 ; 86 \mathrm{tr} / \mathrm{min}$ & 192 \\
Wheat flour type 55 & $365(31.06)$ & $\mathrm{V}=10 ; 286 \mathrm{tr} / \mathrm{min}$ & 60 \\
Deionised water & $80(6.81)$ & $\left.\mathrm{V}=12 \mathrm{~cm}^{3}\right)$ in mould &
\end{tabular}

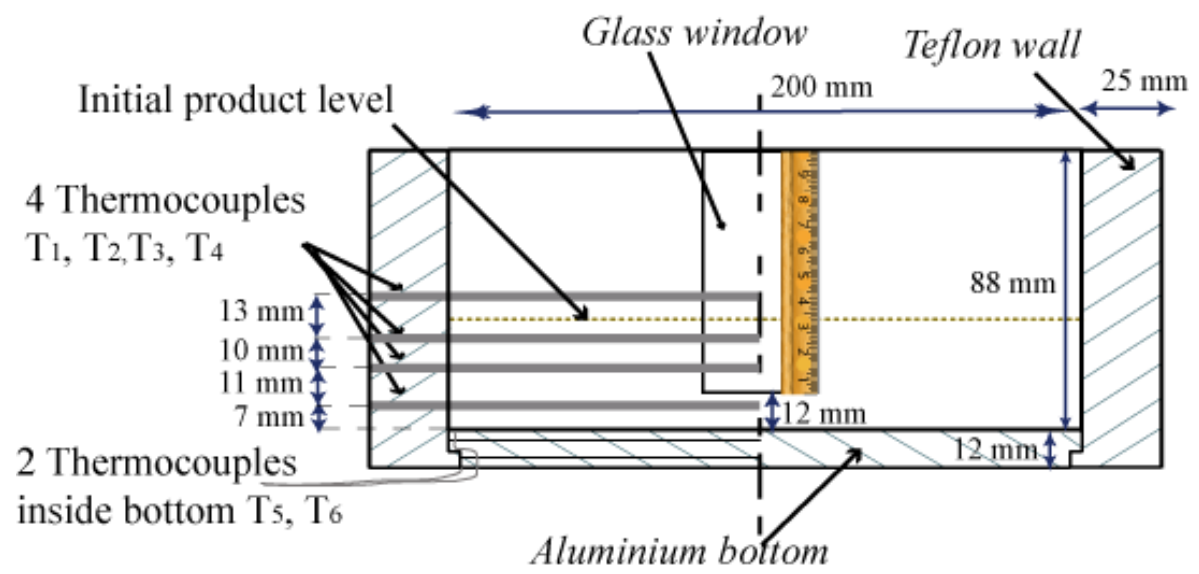

Figure 1: Baking mould $\left(\varnothing=25 \mathrm{~cm} ; \mathrm{h}=10 \mathrm{~cm}\right.$; initial product mass, volume $=700 \mathrm{~g}, 942 \mathrm{~cm}^{3}$ )
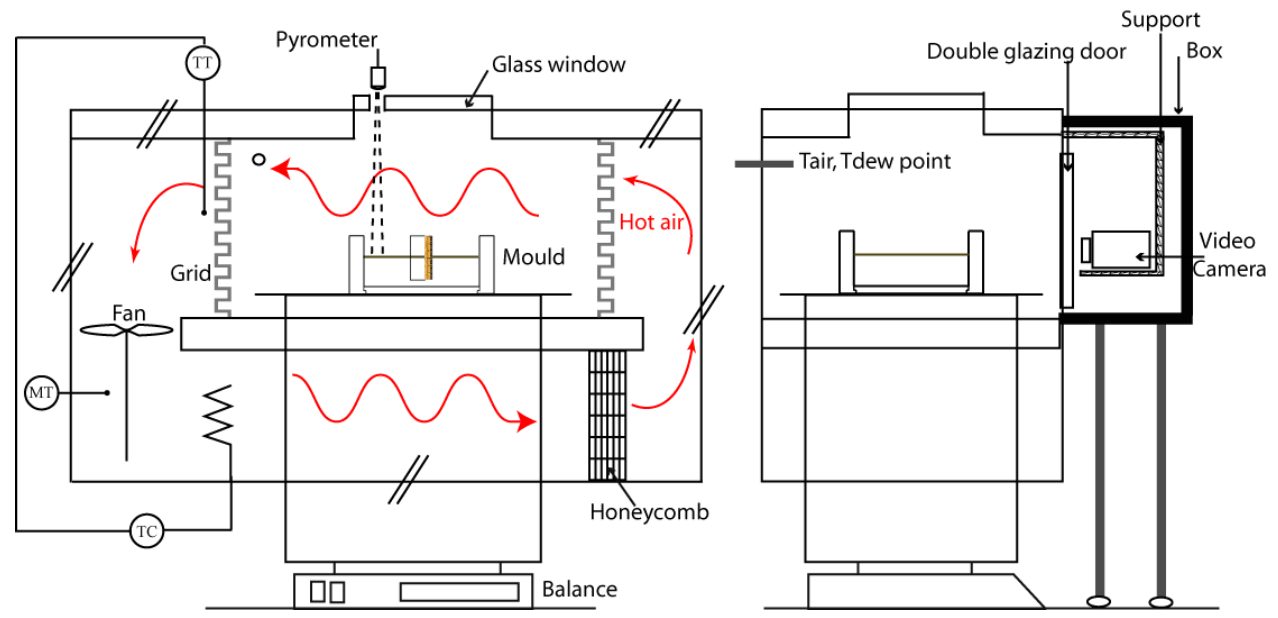

Figure 2: Instrumented pilot oven front and side views 


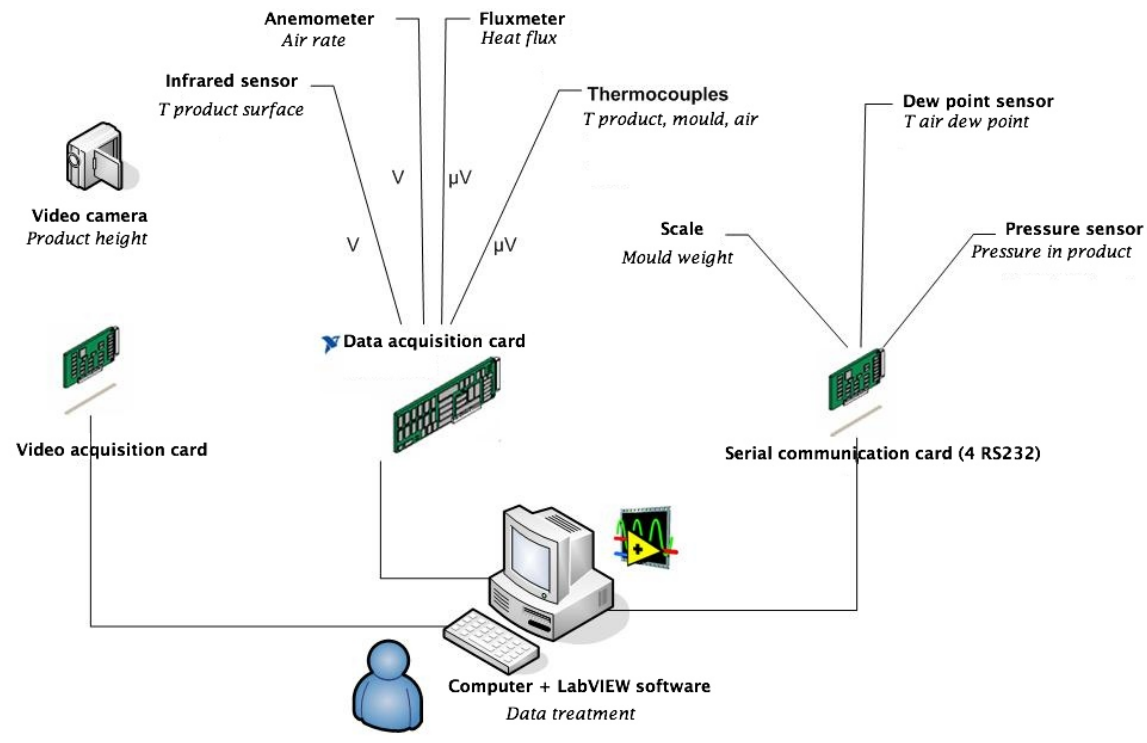

Figure 3: General diagram for data acquisition

\section{Product weight loss}

The mould was laid on a support connected to an electronic balance (51 g - $32 \mathrm{~kg} \pm 1 \mathrm{~g}, \mathrm{SB}$, Mettler Toledo). To measure weight, the fan was stopped for $3 \mathrm{~s}$ every $18 \mathrm{~s}$. For the different trials, heating was stopped after a fixed weight loss corresponding to different durations according to air temperature.

\section{Product and mould temperatures}

Six thermocouples (type $\mathrm{K}, \varnothing=1 \mathrm{~mm}, \pm 0.5$ $\left.{ }^{\circ} \mathrm{C}\right)$ were inserted into stainless steel tubes $(\varnothing=$ $2 \mathrm{~mm}, \mathrm{~L}=100 \mathrm{~mm}$ ) and placed along horizontal sections assumed to be isothermal, to obtain temperatures along an axial direction, four in the centre of the product, T1, T4, and two in the base of the mould, T5, T6 (Fig. 1). At the beginning of baking, three thermocouples were placed in the core of the product (T2, T3, T4) and one in the air (T1) above the product surface. After a period of time, as the product expanded, this last thermocouple ended inside the batter. To record the product surface temperature (centre) during baking in real time, an infrared sensor (MR784231D, Ahlborn), cooled with compressed air, was fixed on the top window of the oven.
Calibration was made with baked sponge cake at ambient temperature. We took part of crust and crushed it in a petri dish. A thin thermocouple was placed in this powder near the surface. Knowing the object temperature, the emissivity could be calculated. The method established a known temperature by using the oven as an equalization box (chamber with air circulation). When we had observed thermal equilibrium we adjusted the emissivity $\mathrm{e}=0.87 \pm 0.02$ to have the same temperature between thermocouple and infrared sensor. In the first minute of baking process the emissivity could be lower than this value (glossy aspect) but the quick increase of surface temperature (from $25^{\circ} \mathrm{C}$ to $110^{\circ} \mathrm{C}$ in $500 \mathrm{~s}$ ) led to a rapid drying of the surface (dull aspect) with the emissivity becoming close to the final one.

\section{Product internal pressure}

The internal total pressure was recorded with an autonomous calibrated sensor placed in the centre of the product during baking. Due to the sensor dimensions $(\mathrm{L}=6 \mathrm{~cm}, \varnothing=3 \mathrm{~cm})$, specific trials were conducted with a larger volume of batter $\left(1413 \mathrm{~cm}^{3}\right.$ instead of $\left.942 \mathrm{~cm}^{3}\right)$. This piezoresistive sensor (NanoVACQ NVQ/PT-TC, TMI-Orion, Fr) may be used for a range from 
Characterization of sponge cake during baking process $\mid 149$

Table 2: Comparison of initial and final densities. (measured and calculated (image analysis))

\begin{tabular}{cccccc}
\multicolumn{2}{c}{ Batter density $\left(\mathrm{kg} / \mathrm{m}^{3}\right)$} & \multicolumn{3}{c}{ Baked product density $\left(\mathrm{kg} / \mathrm{m}^{3}\right)$} \\
\hline measured & calculated & error $\%$ & measured & calculated & error \% \\
\hline 680 & 679 & 0.1 & 385 & 394 & 2.5 \\
680 & 664 & 2.3 & 423 & 404 & 4.3 \\
676 & 673 & 0.4 & 383 & 370 & 3.4
\end{tabular}

30 mbars to 5 bars. It was associated with a Pt100 temperature sensor $\left(0\right.$ to $\left.140{ }^{\circ} \mathrm{C}, \pm 0.1^{\circ} \mathrm{C}\right)$, placed at $14 \mathrm{~mm}$ in the same plane. Recorded data were studied afterwards using $\mathrm{xVACQ}$ software. For the pressure measurements, a greater initial batter volume was needed to cover the sensor, giving an initial height of $4 \mathrm{~cm}$ instead of 2.5 $\mathrm{cm}$. However, the comparison was made using traditional trials by considering the mean product temperatures associated with the measured internal pressure.

\section{Image analysis, height and volume}

During the baking process, the shape of the entire top part of the batter developed into a dome with the highest part in the centre. The top of this dome could be viewed through the mould window and images were taken every 3 minutes (Fig. 2) with a video camera (CDD, Sony, FBCIX47) fixed in front of the double glass door. To enhance contrast, the internal wall of the mould was blackened and the surface illuminated using an optical fibre light. The camera was protected in a box to minimize the external light environment. The images were further analysed to determine product height variation $( \pm 0.5 \mathrm{~mm})$. They were transformed by segmentation and ultimately two zones were retained, corresponding to the product (white) and the mould wall (black) behind the product. Product thickness was measured using a calibrated scale.

The initial batter was considered as a cylinder $\left(\mathrm{R}, \mathrm{H}_{0}\right)$. The initial thickness $\left(\mathrm{H}_{0}\right)$ corresponded to the product adhering to the mould glass window. We assumed that the cylinder part (all through the baking process) was equal to initial volume of dough $\left(\mathrm{V}_{i}\right)$.

$$
V_{i}=H_{0} \cdot \pi \cdot R^{2}
$$

During baking the batter expanded, and a spherical portion appeared $\left(\mathrm{V}_{s}\right)$ that contributed to the final volume.

The total height of the product measured by image analysis $\mathrm{H}(\mathrm{t})$ was equal to initial height of the cylinder $\left(\mathrm{H}_{0}\right)$ and height of the spherical part $\mathrm{h}(\mathrm{t})$

$$
H(t)=h(t)+H_{0}
$$

We used a correction factor $\mathrm{k}$ to take into account shape and dimension of the spherical part and any potential irregular expansion.

The spherical portion volume was equal to

$$
V_{s}=\frac{\pi(k h)}{6}\left(3 R^{2}+(k h)^{2}\right)
$$

The $\mathrm{k}$ factor was determined by comparing volume measurements on the final baked product after cooling by image analysis and by seed displacement method. The value of $\mathrm{k}$ was found to be 1.48 with a maximal variation of $6.9 \%$ for different trials at $160{ }^{\circ} \mathrm{C}$. The $\mathrm{k}$ factor depended on the characteristics of the mould, the product and the oven. At any time the volume could be calculated, and the density obtained by dividing the weight by the volume. Validation of the densities determined from images was also run on the product before and after baking using traditional measurements (Table 2). The mean error value made with the initial batter was small because the images were easy to analyse since the level of batter in the mould was clearly visible. The mean difference was less than $2 \%$ for the initial value and less than $5 \%$ for the value after baking.

\section{Product and mould temperatures}

Special thermal flux meters (Captec, Fr) were designed to detect both radiative and convective 


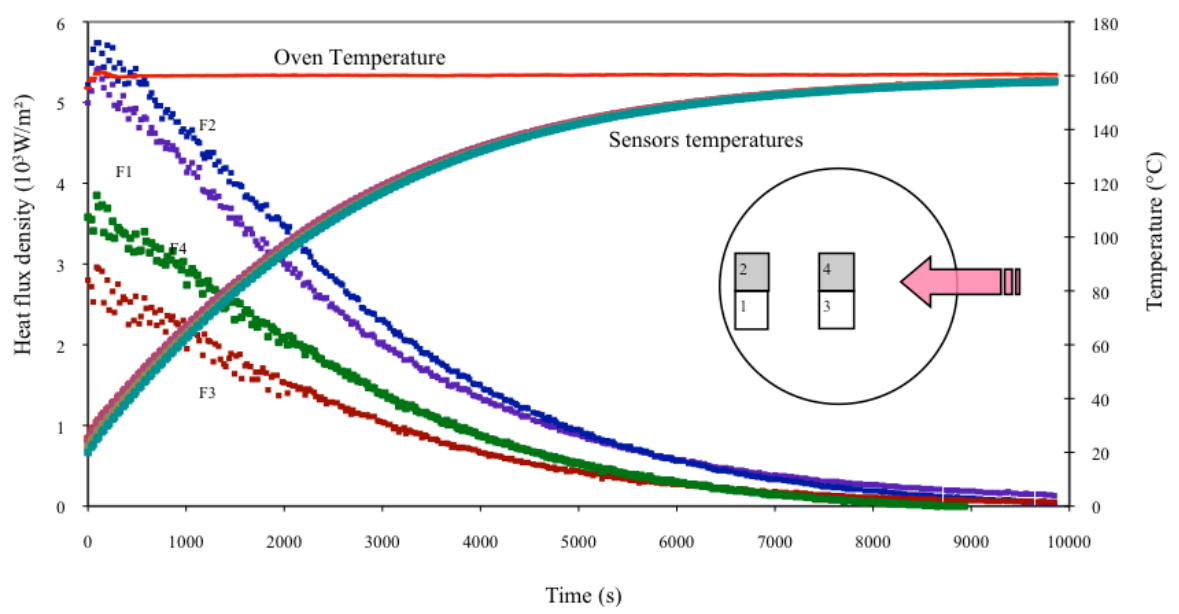

Figure 4: Heat flux measurement with a copper plate in the mould (sensors $2 \times 2 \mathrm{~cm} ;(1,3)$ bright and $(2,4)$ black; plate h $1.5 \mathrm{~cm}, \varnothing 20 \mathrm{~cm})$

flux density $\left(\mathrm{W} / \mathrm{m}_{2}\right)$, using a shiny reflective sensor $(1,3)$ for convective flux, and a blackened one $(2,4)$ for radiative and convective flux (total). The heat flux corresponded to the temperature difference between two plates, measured with a thermopile $\left( \pm 1 \mathrm{~W} / \mathrm{m}^{2}\right)$. Calibration was carried out by the sensor manufacturer. The sensors $(20 \times 20 \times 0.4 \mathrm{~mm})$ were attached to a thin cylindrical copper plate using dried milk for easy removal (Fig. 4). The plate surface lined the internal surface of the empty mould and was placed on insulating supports inside the empty mould, to simulate the initial height of the baking product surface $(3 \mathrm{~cm})$. The sensors were placed in the centre and on the right- and left-hand sides of the mould, to identify possible differences due to air flow direction. The temperatures of the oven walls were measured and were equal to air temperature in the oven. The convective heat flux density was proportional to the difference between air and plate surface temperatures, and to the convective heat transfer coefficient.

$$
\Phi_{\text {convective }}=h_{\text {convective }}\left(T_{\text {air }}-T_{\text {surface sensor }}\right)
$$

\subsection{Experimental conditions}

The study was performed for three air temperature conditions $\left(160-180-220{ }^{\circ} \mathrm{C}\right)$, at a constant air velocity of $3.5 \mathrm{~m} / \mathrm{s}$. The mould was placed in the preheated oven. Heating time was stopped when a fixed weight loss was reached, followed by cooling of the product in the oven. These conditions were found to give the sponge cake a structure and appearance which was suitable for consumers. The air temperature inside the oven was first verified to ensure that it was homogeneous. Experimental data concerning product temperature profiles and density variation are discussed for trials at $160{ }^{\circ} \mathrm{C}$ with a baking time of 81 minutes $(4860 \mathrm{~s})$, and compared with trials at 180 $220{ }^{\circ} \mathrm{C}$.

\section{Results and Discussion}

\subsection{Product behaviour}

The data recorded during a typical baking trial are shown in Figures 5 and 6: air temperature in the oven; weight and temperatures (T1, T2, T3, $\mathrm{T} 4$ and surface) of product; mould base temperatures (T5, T6). The air temperature measured at the outlet inside the oven was stable at 160 ${ }^{\circ} \mathrm{C}(\mathrm{T} 7)$. At $160{ }^{\circ} \mathrm{C}$ the heating time was 4860 $\mathrm{s}$ and cooling time (air circulating without heating) was $6000 \mathrm{~s}$.

The surface temperature $\mathrm{Ts}$ of the batter reached $100{ }^{\circ} \mathrm{C}$ in less than $300 \mathrm{~s}$, then $130{ }^{\circ} \mathrm{C}$ after 1000 
Characterization of sponge cake during baking process $\mid 151$

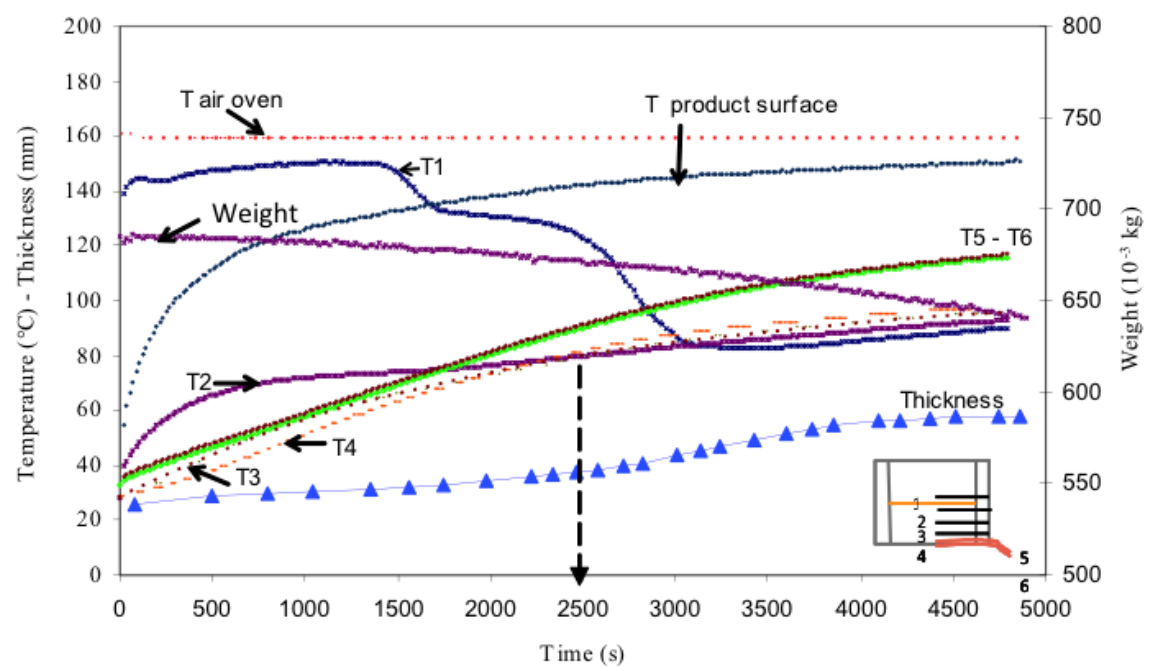

Figure 5: Evolution of different parameters during sponge cake baking (air temperature; T1 to T4: product temperatures; Tproduct surface; T5,6: mould bottom; weight, thickness)

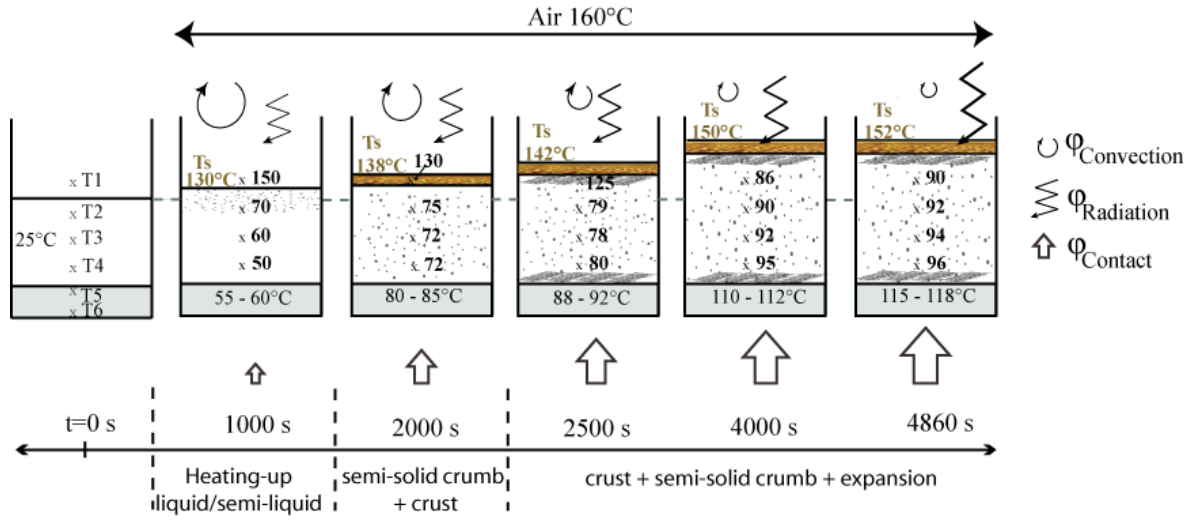

Figure 6: Product temperature profiles and heating fluxes received by the product (air $160^{\circ} \mathrm{C} ; 3.5 \mathrm{~m} / \mathrm{s}$; initial sponge cake volume $=942 \mathrm{~cm}^{3}$; temperatures: Ts surface; T1, T2, T3, T4 product; T5, T6 mould bottom) 


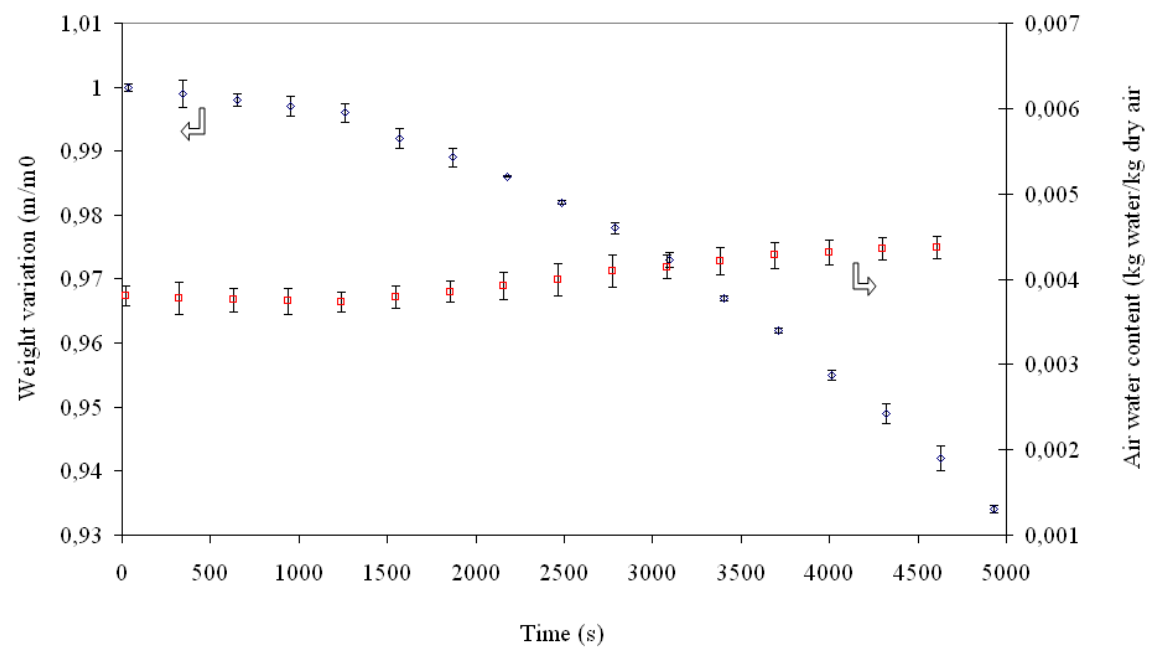

Figure 7: Mass loss kinetics and air water content variation during baking (air $160^{\circ} \mathrm{C}, 3.5 \mathrm{~m} / \mathrm{s} ; \mathrm{m}_{0}$ initial product weight)

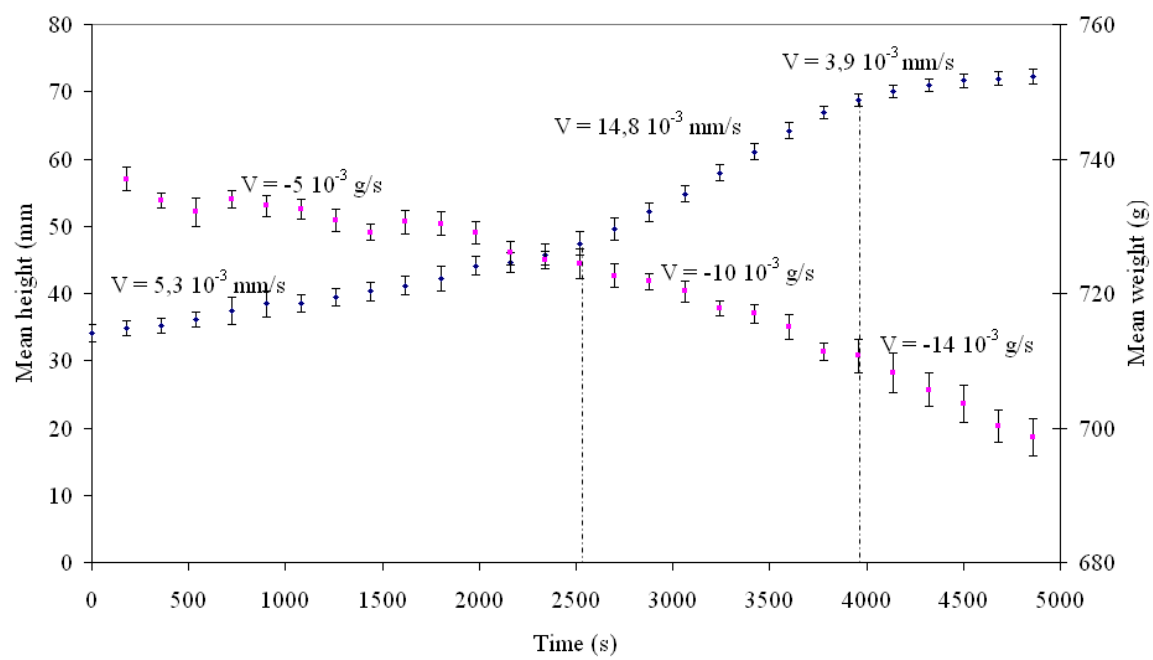

Figure 8: Evolution of sponge cake height and weight during baking (air $160^{\circ} \mathrm{C}, 3.5 \mathrm{~m} / \mathrm{s} ; 4$ trials) 
s, mainly due to air convection above the product surface in the mould. During the first 1000 s mass loss kinetics (Fig. 5, 7) were slow, and were assumed to correspond to water loss via the surface, which rapidly reached a high temperature $\left(120^{\circ} \mathrm{C}\right.$ after $\left.1000 \mathrm{~s}\right)$ due to the circulation of hot air.

Temperatures close to the surface were high enough for the rapid formation of a dry zone, leading to the final coloured crust. Next, there was diffusion of water from inside through the forming crust and crumb, the higher drying rate being observed when the structure was less fluid and expansion was increasing. The average apparent drying rate was calculated to range from $1.4 \times 10^{-5}$ to $3.2 \times 10^{-5} \mathrm{~g}$ water/s.g dry matter, for the two main periods 1000 to $2500 \mathrm{~s}$ and to 4860 s respectively.

After $1400 \mathrm{~s}$, thermocouple 1 came into contact with the expanding product which increased in height by $1 \mathrm{~cm}$. T1 was then measured inside the product, below the surface, and decreased to a plateau of $130{ }^{\circ} \mathrm{C}$, corresponding to the period when the thermocouple was inside the crust (1750-2100 s). The infrared measurement of crust (Fig. 5) crossed T1 at this time. Then $\mathrm{T} 1$ decreased, due to its increasing distance from the surface/crust (expansion), to a temperature where $\mathrm{T} 1$ followed the profile of temperatures inside the moist crumb.

Initially, internal temperature $\mathrm{T} 2$ was measured below but close to the product surface. After $600 \mathrm{~s}, \mathrm{~T} 2$ increased to $65-75{ }^{\circ} \mathrm{C}$, a temperature range corresponding to protein denaturation and the beginning of starch gelatinisation and gluten coagulation (Lostie et al., 2002). Thermocouple 2 was then in a medium which consisted of crumb, with temperatures increasing steadily to $78-80{ }^{\circ} \mathrm{C}$ at $2500 \mathrm{~s}$ and $90-94{ }^{\circ} \mathrm{C}$ at $4860 \mathrm{~s}$.

At first, heat transfer was mainly through the surface, heated by convection from the circulating hot air, and by radiation from the walls of the oven. Heat transfer via the bottom increased during baking as the temperature of the mould base increased $(t>2500 \mathrm{~s})$. The bottom of the mould, initially at room temperature, was heated by contact with the plate (linked to scales). Temperatures T5, T6 were $55-65^{\circ} \mathrm{C}$ after $1000 \mathrm{~s}$, remaining under $100{ }^{\circ} \mathrm{C}$ until $3000 \mathrm{~s}$, and then increasing steadily to $116-118{ }^{\circ} \mathrm{C}$ at the end of bak- ing. This explained the corresponding T4 temperatures in the bottom of the batter, 50 and 85 ${ }^{\circ} \mathrm{C}$ respectively, that reached $96{ }^{\circ} \mathrm{C}$ at the end of baking. Unlike bread or other cake baking studies, the batter temperature did not reach a plateau at $100{ }^{\circ} \mathrm{C}$ because of slower heat transfer (Sommier et al., 2005; Li \& Walker, 1996). The inversion of heat transfer mainly by the bottom after 2500s must be compared to internal pressure and height variation. The heat flux received by the bottom of the product is one of the most important drivers of volume expansion.

The variation in height in three trials showed a good level of precision (Fig. 8). It can be seen that height increased from the beginning of the baking process $(0.005 \mathrm{~mm} / \mathrm{s})$. After $2500 \mathrm{~s}$ major heat transfer was received, then expansion became faster from $2500 \mathrm{~s}$ to $3800 \mathrm{~s}(0.015$ $\mathrm{mm} / \mathrm{s}, 78-90{ }^{\circ} \mathrm{C}$ ), due to the growth of gas cells. After $4000 \mathrm{~s}$, the height reached a plateau with a mean temperature in the crumb of around 90 ${ }^{\circ} \mathrm{C}$. This corresponded to a stable crumb structure, whereas the water loss continued. The initial height $(26 \mathrm{~mm})$ more than doubled $(58 \mathrm{~mm})$ by the end of baking. The mode of heating prevented some of the final shrinking observed in other studies (Lostie et al., 2002). The final product consisted of a moist main part (crumb) with many small open cells $(<1 \mathrm{~mm})$ and an upper thin brown dry crust $(2 \mathrm{~mm})$, with under the crust, a $0.5 \mathrm{~cm}$ part with some bigger cells $(\sim 2$ $\mathrm{mm})$.

The rise in internal pressure could explain part of the volume expansion with competition between swelling of the product (bubble growth due to the increase in temperature), the batter stiffening and, in some cases, a change from close to open porosity. During the baking time the internal pressure increased slowly until a variation of 6 mbar was reached between $60{ }^{\circ} \mathrm{C}$ and 75 $80{ }^{\circ} \mathrm{C}$ (Fig. 9) (Sommier et al., 2002). When the temperature was lower than $60{ }^{\circ} \mathrm{C}$, the continuous phase of the batter showed little resistance to deformation, with the presence of small cells. Then the pressure increased because of the higher temperature, with physico-chemical reactions creating a more rigid structure (proteins, gluten, starch) which was able to expand. In the case of the sponge cake the cells were small and regular in the batter and still small in the final 
crumb. The biggest cells in the final cake were mainly observed just under the crust, where the heating was more intense, with higher temperatures especially in the second period after $2500 \mathrm{~s}$. With no leavening agent in the recipe, the cells were filled only with air introduced during the batter preparation, and water vapour, both contributing to the thermal expansion (Matz, 1972; Dunn \& White, 1939; Pyler, 1973; Baik \& Marcotte, 2003; Sommier et al., 2002). Beyond 80 ${ }^{\circ} \mathrm{C}$ in the product, the pressure increased more rapidly: this " $80{ }^{\circ} \mathrm{C}$ " temperature in the product corresponded to "time $2500 \mathrm{~s}$ " in a traditional trial, when the expansion became greater. However, in the case of bread, after the period of pressure increase, we observe a decrease then a plateau, which would suggest a transition from closed porosity to open porosity following the coalescence of the air bubbles and slashing with a knife (scarification) (Sommier et al., 2002). With the sponge cake, the pressure increased throughout the trial, which suggested that the porosity was enclosed within the crust; the bubbles were more distinct and as the crust formed, this fixed the upper structure of the product.

\subsection{Influence of baking temperature on density}

Three baking temperatures were used (160, 180 and $220^{\circ} \mathrm{C}$ ) for the same weight loss. Density was calculated for each acquisition time as the ratio of mass to volume (Fig. 8, 10). The evolution of density was linked to water loss and the way it was lost, through the semi-liquid batter then the crumb, and to the formation and the increasing resistance of the crust at the surface. Rate of weight loss varied in the different phases, slow for $1000 \mathrm{~s}$ then increasing more quickly after $2500 \mathrm{~s}$ when the structure was more rigid. At first, the free water evaporated from the semi-liquid batter, but a thin crust quickly formed due to a high surface temperature $\left(110{ }^{\circ} \mathrm{C}\right.$ at $\left.500 \mathrm{~s}\right)$, limiting water loss. This corresponded to a small variation in total volume, resulting in a slow decrease in density.

During the second period, between 2500 and $3500 \mathrm{~s}$, expansion accelerated, corresponding to a certain homogeneity and increase in mean tem- perature inside the batter; the evaporation rate was constant as the crumb formed. This meant a high variation in density. After $3500 \mathrm{~s}$ the crust was thicker and more rigid. This prevented further expansion, tending to limit water loss.

After the sponge cake baking process (81 $\mathrm{min}$ at $\left.160{ }^{\circ} \mathrm{C}\right)$, total weight loss was rather low $(6$ $\%$, while density was half of the initial value $\left(\sim 700\right.$ to $\left.350 \mathrm{~kg} / \mathrm{m}^{3}\right)$. At a higher air temperature (i.e. $220^{\circ} \mathrm{C}$ ) it was observed that expansion was slightly greater (Fig. 11). Consequently the final apparent density of the sponge cake was 340 $\mathrm{kg} / \mathrm{m}^{3}$ compared to 400 and 355 at 160 and 180 ${ }^{\circ} \mathrm{C}$ respectively.

\subsection{Dissymmetry in the final product}

The final products presented differences of height and colour between the right, centre and left parts. They were browner and lower on the left side (opposite the hot air inlet). The variations in heat fluxes affected the symmetry of product expansion and surface colour. Heat flux sensors were placed on the copper plate in the mould (Fig. 3), and measurements in the centre $(1,4)$ showed good repeatability with $75 \%$ of convective flux and $25 \%$ of radiative flux (difference between total (black) and convective (bright)). From the measurements with the bright sensor, the convective coefficient $h$ was calculated as equal to $20 \mathrm{~W} / \mathrm{m}^{2} . \mathrm{K}$ in the centre. The radiative flux was found to be $10 \%$ (left), $25 \%$ (centre), 35 $\%$ (right). This was deduced from observations of the convective flux which was greater on the left-hand side, opposite the hot air inlet, perpendicular to the right wall of the mould. During baking, this greater convective flux on the lefthand side resulted in faster drying on the surface of the batter locally, which fixed the structure so that the height of the product was less on the left than on the right where it could expand more easily. It also resulted in a darker colour on the left-hand side of the finished product.

By measuring and interpreting the respective contributions of the different heat fluxes received by the product it was possible to explain product expansion and/or colour. In our experiments the mould was heated by hot air flowing on 
Characterization of sponge cake during baking process $\mid 155$

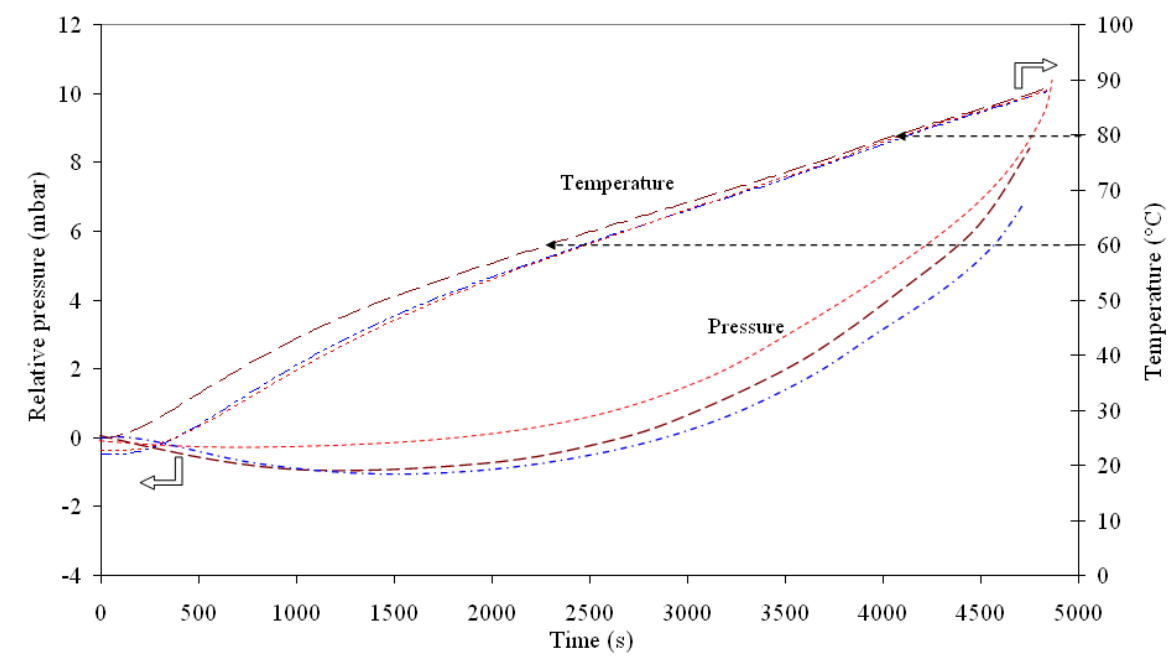

Figure 9: Evolution of sponge cake internal pressure and temperature during baking (air $160^{\circ} \mathrm{C}, 3.5 \mathrm{~m} / \mathrm{s}$, initial product volume $=1413 \mathrm{~cm}^{3} ; 3$ trials)

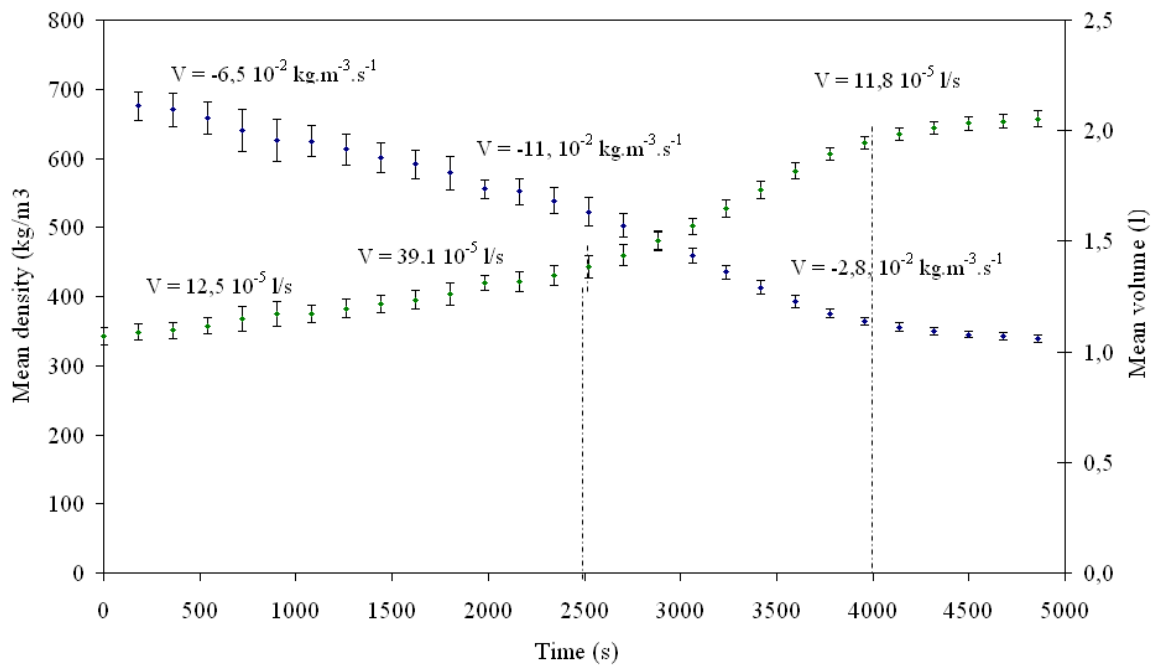

Figure 10: Volume and density variation during sponge cake baking (air $160^{\circ} \mathrm{C}, 3.5 \mathrm{~m} / \mathrm{s}$, initial product volume $=942 \mathrm{~cm}^{3} ; 4$ trials) 


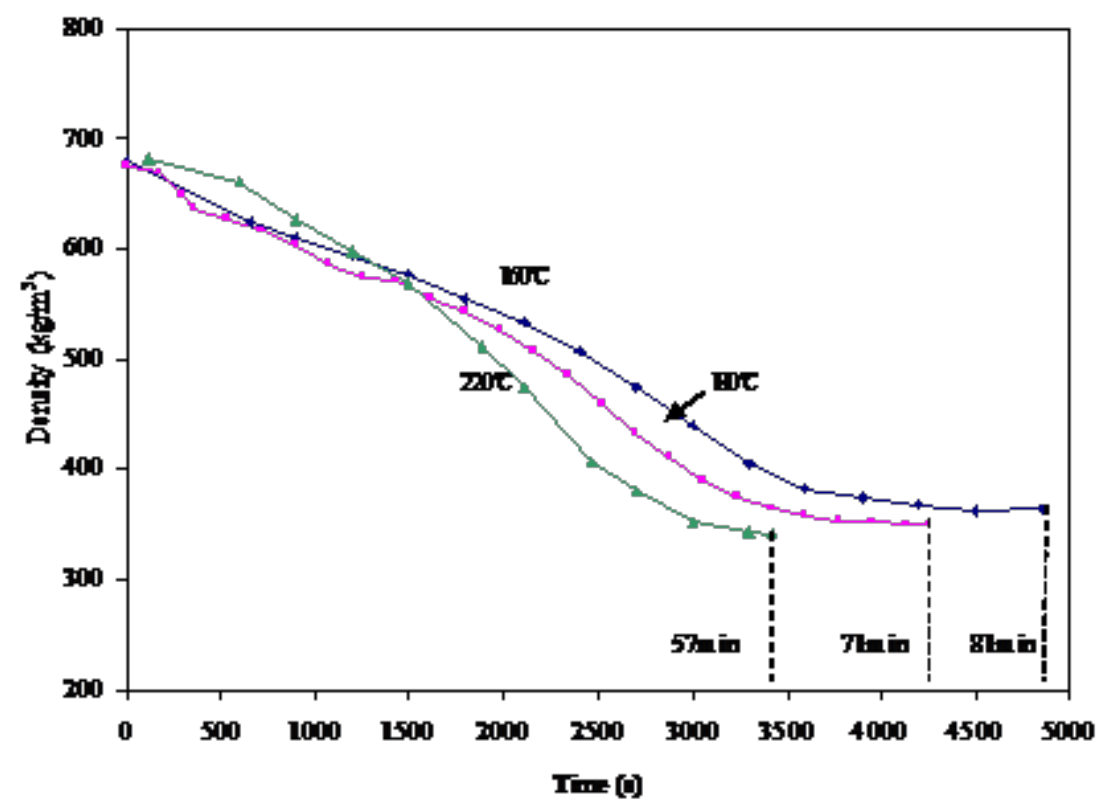

Figure 11: Density variation during sponge cake baking at different air temperatures $\left(160-180-220^{\circ} \mathrm{C}\right)$

one side only, producing non-symmetrical heat fluxes. This situation could be improved with a rotating tray, to ensure that the heat flux reached the product evenly, or with hot air blown on each side of the mould alternately after each weighing.

\section{Conclusions}

Specific instrumentation was developed to collect as much information as possible about a model product as it was being baked. Product temperatures (surface and core), internal pressure, thickness, weight and heat fluxes were evaluated at different baking temperatures $\left(160-180-220^{\circ} \mathrm{C}\right)$, during times leading to the same weight loss for the product. Images of the rising product surface were recorded and analysed for height variation, and combined with weight to calculate density. The approach with heat flux readings in ovens to explain colour and/or expansion was applied as a diagnostic tool in different industrial ovens (Sommier, Anguy, Dumoulin, Rojas, \& Vignolle, 2011).

These combined data gave a better understand- ing of the transfer phenomena that take place during baking into the product, and should lead to better process design and control. In order to obtain a light and airy final sponge cake (density, height), the time and heat given to the product to increase in volume is important. During this period the respective proportion of heat flux received by the surface should be small compared with that received by the base of the product. This phase slows the drying phenomenon which causes the crust to form and fixes the structure thus stopping further expansion. At the end of baking, these respective lower/upper flux proportions can be reversed to finalise browning if needed.

\section{References}

Baik, O. D., \& Marcotte, M. (2003). Modeling the moisture diffusivity in a baking cake. Journal of Food Engineering, 56 (1), 27-36. doi: $\{10.1016 /$ S0260-8774(02)00144-9\}

Baik, O. D., Marcotte, M, \& Castaigne, F. (2000a). Cake baking in tunnel type multizone industrial ovens - Part I. Characteri- 
Characterization of sponge cake during baking process $\mid 157$

zation of baking conditions. Food Research International, 33(7), 587-598. doi: $\{10$. 1016/S0963-9969(00)00095-8\}

Baik, O. D., Marcotte, M, \& Castaigne, F. (2000b). Cake baking in tunnel type multizone industrial ovens - Part II. Evaluation of quality parameters. Food Research International, 33(7), 599-607. doi:\{10.1016/ S0963-9969(00)00096-X\}

Baik, O. D., Sablani, S. S., Marcotte, M, \& Castaigne, F. (1999). Modeling the thermal properties of a cup cake during baking. Journal of Food Science, 64(2), 295-299. doi:\{10.1111/j.1365-2621.1999.tb15886.x $\}$

Baker, B. A., Davis, E. A., \& Gordon, J. (1990). Glass And Metal Pans For Use With Microwave and Conventionally Heated Cakes. Cereal Chemistry, 67(5), 448-451.

Bakshi, A. S., \& Yoon, J. (1984). Thermophysical properties of bread rolls during baking. Lebensm. Wiss. und. Technol. 17(2), 9093.

Chevallier, S, Della Valle, G, Colonna, P, Broyart, B, \& Trystram, G. (2002). Structural and chemical modifications of short dough during baking. Journal of Cereal Science, 35 (1), 1-10. doi: $\{10.1006 /$ jcrs.2001.0388\}

Dunn, J. A., \& White, J. R. (1939). The leavening action of air included in cake batter. Cereal Chemistry, 16, 93-100.

Fahloul, D, Trystram, G, Mcfarlane, I, \& Duquenoy, A. (1995). Measurements And Predictive Modeling Of Heat Fluxes In Continuous Baking Ovens. Journal of Food Engineering, 26(4), 469-479. doi:\{10.1016/ 0260-8774(94)00070-P\}

Hasatani, M, Arai, N, Harui, H, Itaya, Y, Fushida, N, \& Hori, C. (1992). Effect of Drying on Heat-Transfer of Bread During Baking in Oven. Drying Technology, 10(3), 623-639. doi:\{10.1080/ $07373939208916468\}$

He, H, \& Hoseney, R. C. (1991). Gas Retention in Bread Dough During Baking. Cereal Chemistry, 68(5), 521-525.

Hwang, M. P., \& Hayakawa, K. I. (1980). Bulk Densities of Cookies Undergoing Commercial Baking Processes. Journal of Food Science, 45(5), 1400-\&. doi: $\{10.1111 / \mathrm{j} .1365-$ 2621.1980.tb06563.x
Jefferson, D. R., Lacey, A. A., \& Sadd, P. A. (2007). Crust density in bread baking: Mathematical modelling and numerical solutions. Applied Mathematical Modelling, $31(2)$, 209-225. doi: $\{10.1016 /$ j.apm.2005. $08.017\}$

Jefferson, D. R., Lacey, A. A., \& Sadd, P. A. (2006). Understanding crust formation during baking. Journal of Food Engineering, 75(4), 515-521. doi:\{10.1016/ j . jfoodeng.2005.04.051\}

Li, A, \& Walker, C. E. (1996). Cake baking in conventional, impingement and hybrid ovens. Journal of Food Science, 61 (1), 188\&. doi:\{10.1111/j.1365-2621.1996.tb14756. $\mathrm{x}\}$

Lostie, M, Peczalski, R, Andrieu, J, \& Laurent, M. (2002). Study of sponge cake batter baking process. Part I: Experimental data. Journal of Food Engineering, 51(2), 131137. doi: $\{10.1016 /$ S0260-8774(01)00049-8\}

Matz, S. A. (1972). Formulations and procedures for air-leavened, steam-leavened, and unleavened products, (pp. 165-187). In Bakery technology and engineering ( $2^{\text {nd }}$ ed.). AVI Publishing Co., Westport, Conn.

McFarlane, I. (1992). Travelling heat flux sensor. In ICHEME Symposium Series $N^{o} 126$, Food engineering in a computer climate, held at Cambridge (UK), 30 March-1 ${ }^{\text {st }}$ April., (pp. 351-358). Cambridge: Institute of Chemical Engineers.

Pierrel, F., \& Newborough, M. (2003). Heat flux maps for ovens: concept of baking comfort zones. ASME Conference Proceedings, 2003(37254), 119-128. doi:\{10.1115/ IMECE2003-41891\}

Pyler, E. J. (1973). Baking science and technology. Siebel Publishing Co., Chicago, Ilinois, Vol 2.

Sato, H, Matsumura, T, \& Shibukawa, S. (1987). Apparent Heat-Transfer in a ForcedConvection Oven and Properties of Baked Food. Journal of Food Science, 52(1), 185\&. doi:\{10.1111/j.1365-2621.1987.tb14001. $\mathrm{x}\}$

Sommier, A, Chiron, H, Colonna, P, Della Valle, G, \& Rouille, J. (2005). An instrumented pilot scale oven for the study of French bread baking. Journal of Food Engineering, 
69(1), 97-106. doi:\{10.1016/j.jfoodeng . 2004.07.015\}

Sommier, A, Ben Yaghlane, H, \& Broyart, B. (2002). Les transferts de chaleur et de matière. Application à une mousse solide : la génoise. Industries des céréales, 127, $12-18$.

Sommier, A, Anguy, Y, Dumoulin, E, Rojas, J, \& Vignolle, M. (2011). On the use of combined heat flux measurements and image analysis procedures for the change of scale between industrial and pilot ovens. Procedia Food Science, 1, 1165-1172. 11th International Congress on Engineering and Food (ICEF11). doi: $\{10.1016 / \mathrm{j}$. profoo . 2011.09.174\}

Standing, C. N. (1974). Individual Heat-transfer Modes In Band Oven Biscuit Baking. Journal of Food Science, 39(2), 267-271. doi: $\{10.1111 / j .1365-2621.1974 . t b 02872 . x\}$

Sumnu, G, Sahin, S, \& Sevimli, M. (2005). Microwave, infrared and infrared-microwave combination baking of cakes. Journal of Food Engineering, 71 (2), 150-155. doi: $\{10$. 1016/j.jfoodeng.2004.10.027\}

Zareifard, M. R., Marcotte, M, \& Dostie, M. (2006). A method for balancing heat fluxes validated for a newly designed pilot plant oven. Journal of Food Engineering, 76(3), 303-312. doi:\{10.1016/j.jfoodeng.2005.05. $037\}$ 